\title{
Comparing the accuracy of three non-destructive methods in estimating aboveground plant biomass
}

\author{
G. Ónodi1 ${ }^{1,4}$, Gy. Kröel-Dulay ${ }^{1,2}$, E. Kovács-Láng ${ }^{1}$, P. Ódor ${ }^{1}$, Z. Botta-Dukát ${ }^{1}$, \\ B. Lhotsky ${ }^{1}$, S. Barabás ${ }^{3}$ J. Garadnai ${ }^{1}$ and M. Kertész ${ }^{1}$ \\ ${ }^{1}$ MTA Centre for Ecological Research, Institute of Ecology and Botany, Alkotmány u. 2-4, H-2163 Vácrátót, Hungary \\ ${ }^{2}$ MTA Centre for Ecological Research, GINOP Sustainable Ecosystems Group, Klebelsberg Kuno u. 3, H-8237 Tihany, \\ Hungary \\ ${ }^{3}$ Corvinus University of Budapest, Department of Botany, Ménesi út 44, H-1118 Budapest, Hungary \\ ${ }^{4}$ Corresponding author. Email: onodi.gabor@okologia.mta.hu, Fax: +3628360 122/110
}

Keywords: Biomass proxies, Coefficient of determination, Field experiment, Field spectroscopy, Point intercept method, Semiarid grassland, Visual cover estimation.

\begin{abstract}
Aboveground plant biomass is one of the most important features of ecosystems, and it is widely used in ecosystem research. Non-destructive biomass estimation methods provide an important toolkit, because the destructive harvesting method is in many cases not feasible. However, only few studies have compared the accuracy of these methods in grassland communities to date. We studied the accuracy of three widely used methods for estimation of aboveground biomass: the visual cover estimation method, the point intercept method, and field spectroscopy. We applied them in three independent series of field samplings in semi-arid sand grasslands in Central Hungary. For each sampling method, we applied linear regression to assess the strength of the relationship between biomass proxies and actual aboveground biomass, and used coefficient of determination to evaluate accuracy. We found no evidence that the visual cover estimation, which is generally considered as a subjective method, was less accurate than point intercept method or field spectroscopy in estimating biomass. Based on our three datasets, we found that accuracy was lower for the point intercept method compared to the other two methods, while field spectroscopy and visual cover estimation were similar to each other in the semi-arid sand grassland community. We conclude that visual cover estimation can be as accurate for estimating aboveground biomass as other approaches, thus the choice amongst the methods should be based on additional pros and cons associated with each of the method and related to the specific research objective.
\end{abstract}

Nomenclature: The Plant List (2010).

Abbreviations: ANPP-Aboveground Net Primary Productivity, NDVI-Normalized Differential Vegetation Index.

\section{Introduction}

Aboveground plant biomass, as a key variable of the primary production assessment (Scurlock et al. 2002), is one of the most important features of ecosystems (Nemani et al. 2003). It is widely used in ecosystem research, including observational (Knapp et al. 2015, Sala et al. 1988), experimental (Fay et al. 2011; Grime et al. 2008), and modelling studies (Scurlock et al. 2002). Harvesting is the conventional method for aboveground biomass estimation by means of removing, separating into fractions, drying and weighing plant material (Sala and Austin 2000). This method can be used in observational studies (Sala et al. 1988), in field experiments with sufficiently large plots (Fay et al. 2011), or in ecosystems that are grazed or mown (Gilgen and Buchmann 2009), where biomass removal is the normal management. However, there are reasons for which non-destructive methods are preferred (Paruelo et al. 1997). Harvesting is labour intensive (Jobbágy et al. 2002), and furthermore, in field experiments with small permanent quadrats it is often not practical to use destructive method (Kongstad et al. 2012). Non-destructive biomass estimation provides biomass proxies as important toolkits for long-term ecosystem experiments. However, the accuracy of the proxies should be evaluated in comparative studies.

Several non-destructive methods have been suggested and used for estimating aboveground biomass and aboveground net primary productivity (ANPP) (Byrne et al. 2011, Sala and Austin, 2000, Wilson, 2011), but there is not a single universal approach applied in ecological studies. The choice of the method may depend on several factors including the purpose of the research, the structure of the vegetation, the size of the area to be assessed, repeatability of the sampling, accuracy required, scientific traditions, time and workforce available (Catchpole and Wheeler, 1992). In grass and shrub dominated communities, the most widely used methods for estimating aboveground biomass are: (1) visual cover estimation of abundance (Braun-Blanquet, 1932, Peet et al. 1998, Sykes et al. 1983), (2) line intercept (Canfield, 1941) and point intercept (Goodall, 1952, Jonasson, 1988) methods, and more recently, (3) ground-based remote sensing techniques, such as field spectroscopy (Milton et al. 2009, Pearson et al. 
1976), light interception methods (Asrar et al. 1986) and image analysis (Röttgermann et al. 2000).

Various arguments have been raised in the literature for and against the different non-destructive methods. Visual cover estimation is a traditional, quick and cost-efficient method (Hahn and Scheuring, 2003, Klimeš, 2003, Peet et al. 1998), but is often considered unrepeatable (Greig-Smith, 1983) and subjective (Wilson, 2011, but see Klimeš, 2003). Many authors argue for the use of point intercept method because of its high accuracy and repeatability (Bråthen and Hagberg, 2004, Frank and McNaughton, 1990, Jonasson, 1988), but it requires relatively high sampling effort compared to other indirect methods (Byrne et al. 2011). Field spectroscopy is characterized by objectivity and quickness (Byrne et al. 2011, Milton et al. 2009), but it provides only a cumulative estimate for vegetation abundance as it cannot differentiate between species or life forms. While many studies apply one of these methods for estimating aboveground biomass, there are very few studies that compare different methods (GodínezAlvarez et al. 2009, Sykes et al. 1983) and even fewer test the accuracy of multiple methods in estimating biomass (Byrne et al. 2011, Redjadj et al. 2012, Whitbeck and Grace, 2006). No studies to date have compared all the three major methods, the visual cover estimation, the point intercept, and the field spectroscopy.

The overall objective of this study was to compare the accuracy of three frequently used aboveground biomass estimation methods, namely visual cover estimation, point intercept method, and field spectroscopy. We wanted to test if the quick and traditionally used visual cover estimation method performed poorly compared to other methods that are often considered more objective in estimating aboveground biomass. In three independent series of field samplings, we compared the accuracy of the proxy data obtained by the above mentioned methods against direct biomass harvest. In particular, we asked if there were differences in accuracy among visually estimated cover, number of point hits, and normalized differential vegetation index (NDVI) in semiarid grasslands.

\section{Materials and methods}

\section{Site description}

Studies were conducted in the area of the Kiskunság National Park, in the Fülöpháza ( $\mathrm{N} 46^{\circ} 52^{\prime}$, E $19^{\circ} 25^{\prime}$ ) site, and in the Orgovány ( $46^{\circ} 47^{\prime}$, E $19^{\circ} 28^{\prime}$ ) site of the KISKUN LTER project (Kovács-Láng et al. 2008), Central Hungary. The climate of the study area is temperate continental with sub-Mediterranean influence. Mean annual precipitation is around $500 \mathrm{~mm}$; mean monthly temperatures ranges from $-2{ }^{\circ} \mathrm{C}$ in January to $21{ }^{\circ} \mathrm{C}$ in July (Kovács-Láng et al. 2000). The soil is calcaric arenosol with low humus content $(<1 \%)$. In each study we sampled the forest-steppe vegetation of the Kiskunság Sand Ridge Area (Molnár, 2003), which is a mosaic of open calcareous grasslands and shrub patches dominated by poplars (Populus alba and Populus nigra) and common juniper (Juniperus communis). The vegetation has a semi-desert character due to the extreme soil moisture regime of the wind-blown coarse sandy soil (Kovács-Láng et al. 2000). In the present study we sampled grasslands, which also included shrubby root suckers of Populus alba. The wide biomass range applied in our study covered the range of natural vegetation types and allowed a good performance of biomass proxies.

\section{Sampling}

We used three datasets to analyse the relationship between aboveground live plant biomass and different biomass sampling methods to study the applicability of biomass proxies obtained from non-destructive sampling and harvested biomass. These datasets belong to ongoing long-term studies.

- Dataset 2002: visual cover estimation and point intercept method in nine elongated plots of $0.2 \mathrm{~m} \times 3 \mathrm{~m}$, in June 2002 , in the Fülöpháza site, as part of the preparation for the VULCAN field experiment (Peñuelas et al. 2007).

- Dataset 2010: visual cover estimation, point intercept method, and field spectroscopy in ten, $1 \mathrm{~m} \times 1 \mathrm{~m}$ quadrats in June 2010, in the Fülöpháza site in order to check the non-destructive biomass estimation proxies applied in the VULCAN and INCREASE field experiment (KröelDulay et al. 2015).

- Dataset 2014: visual cover estimation and field spectroscopy measurements in $16,0.5 \mathrm{~m} \times 0.5 \mathrm{~m}$ quadrats in June 2014, in the Orgovány site along the preparations for a new climate change field experiment.

In all cases, aboveground vascular plant biomass was harvested in each sampling plot after conducting non-destructive estimation methods. The biomass of live materials (green and woody parts) separated from standing dead and litter components were used during the analysis. Biomass samples were dried at $60{ }^{\circ} \mathrm{C}$ until weight constancy and weighed. We contrasted annual live biomass to biomass proxy values obtained from biomass estimation methods. Biomass measurements did not provide enough data for species level calibrations of proxy methods because the sample sizes and biomass ranges for unique species were not large enough.

For visual cover estimation, we recorded the cover values of each vascular plant species adding percentage values between 0 and 100. As a proxy for aboveground biomass, we used the total canopy cover of vascular plant species. Overlaps in cover were considered in the case of multilevel canopy, thus total canopy cover could reach values higher than 100 percent. In the case of Dataset 2002, each $0.2 \mathrm{~m} \times 3$ $\mathrm{m}$ sampling plot was divided into six $0.2 \mathrm{~m} \times 0.5 \mathrm{~m}$ subplots, where subsamples of visual cover estimation were conducted. Values of subsamples were averaged in each plot. Decimal fractions of percentage values were used at the low end of the range (below 2\%) because finer resolution is needed at the ends of the scale (Hahn and Scheuring, 2003). Visual cover estimation has low expected errors at the plot sizes of our study (Klimeš, 2003). Sampling was performed by the same person (G. Ónodi) in Datasets 2010 and 2014 and by G. Kröel-Dulay in Dataset 2002. The possible bias was further 
reduced by adjustments with other experienced persons before each series of estimations, in accordance with previous recommendations (Sykes et al. 1983, Wintle et al. 2013).

Point intercept method (Goodall, 1952, Jonasson, 1988) was applied along transects, at $5 \mathrm{~cm}$ intervals. In the case of Dataset 2002, each sampling plot contained one transect of 57 points. In Dataset 2010, three parallel one-meter transects were used, evenly spaced within the $1 \mathrm{~m}^{2}$ quadrat $(3 * 20=60$ points). During sampling, a metal pin was lowered at $5 \mathrm{~cm}$ intervals along a metal frame, fixed at the two ends and having a horizontal bar at $80 \mathrm{~cm}$ height. At each sampling point, all hits were recorded, together with species identity and state (live or dead). Therefore, the number of point hits can be higher than the number of points. For the current study, we used frequency data on live touches of all species combined as a biomass proxy. The sampling of both datasets was carried out by the same person (J. Garadnai), who was experienced in both the study object and the sampling technique.

Field remote sensing data were collected by using field spectroscopy techniques. We measured the incoming and the reflected light intensity using a portable Cropscan MSR87 multispectral radiometer (Cropscan, Inc., Rochester, MN) in each quadrat. We levelled the sensors of the instrument at 2.8 meters height for the Dataset 2010 ( $1 \mathrm{~m}^{2}$ quadrats $)$, and at 1.8 meters height for the Dataset 2014 (0.25 $\mathrm{m}^{2}$ quadrats) above the centre of the quadrats. The sampling of both datasets was carried out by the same experienced person (G. Ónodi). We calculated NDVI (Rouse et al. 1974) values based on the equation:

$$
\mathrm{NDVI}=\left(\mathrm{NIR}_{810}-\mathrm{R}_{660}\right) /\left(\mathrm{NIR}_{810}+\mathrm{R}_{660}\right)
$$

where $\mathrm{NIR}_{810}$ is the reflectance measured by the near-infrared (NIR) channel (centred at $810 \mathrm{~nm}$, bandwidth $10 \mathrm{~nm}$ ) and $\mathrm{R}_{660}$ is the reflectance measured by the red (R) channel (centred at $660 \mathrm{~nm}$, bandwidth $10 \mathrm{~nm}$ ) of the instrument.

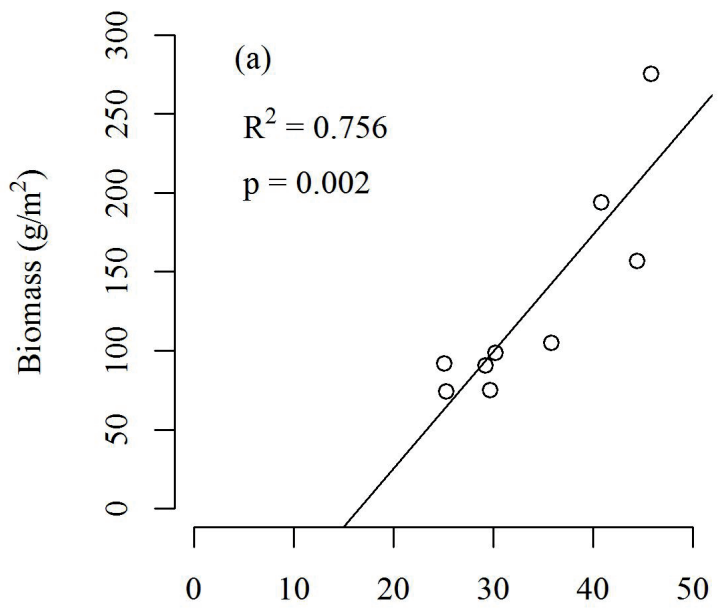

Visually estimated cover (\%)
NDVI is correlated with the amount of green vegetation (Tucker and Sellers, 1986), and is widely used as a proxy for aboveground net primary production in temperate perennial grasslands (Paruelo et al. 1997). NDVI is mostly determined by the leaf area index (Roujean and Breon, 1995), and it goes to saturation in dense vegetation (Gu et al. 2013). However, in the open vegetation of our studies total leaf area index was between 0 and 2 in each quadrat, which is a range not affected by saturation (Gamon et al. 1995).

\section{Statistical analyses}

For all datasets, the relationships between biomass proxies as explanatory variables (visually estimated cover, number of point hits, or NDVI) and harvested biomass as dependent variable were tested by linear regression (Faraway, 2005), in accordance with numerous relevant studies (Jonasson, 1988, Redjadj et al. 2012, Röttgermann et al. 2000). The accuracy of the studied proxies was characterized by the coefficient of determination $\left(\mathrm{R}^{2}\right)$. All analyses were carried out in $\mathrm{R}(\mathrm{R}$ Core Team, 2013).

\section{Results}

In case of the Dataset 2002, linear regression yielded significant positive relationship between the values of visual cover estimation and aboveground live biomass $\left(\mathrm{R}^{2}=0.756\right.$, $\mathrm{F}=21.71, \mathrm{df}=7, \mathrm{p}=0.002$, Fig. 1a). Point intercept and biomass was related only marginally significantly $\left(R^{2}=0.420, F\right.$ $=5.07, \mathrm{df}=7, \mathrm{p}=0.059$, Fig. $1 \mathrm{~b}$ ).

The analysis of the Dataset 2010 resulted in significant relationships between biomass proxies (visually estimated cover, number of point hits, NDVI) and aboveground biomass (Fig. 2). Field spectroscopy showed the highest accuracy (Fig. $2 c, R^{2}=0.838, F=41.31, d f=8, p<0.001$ ), followed by visual cover estimation (Fig. $2 \mathrm{a}, \mathrm{R}^{2}=0.693, \mathrm{~F}=18.04$,

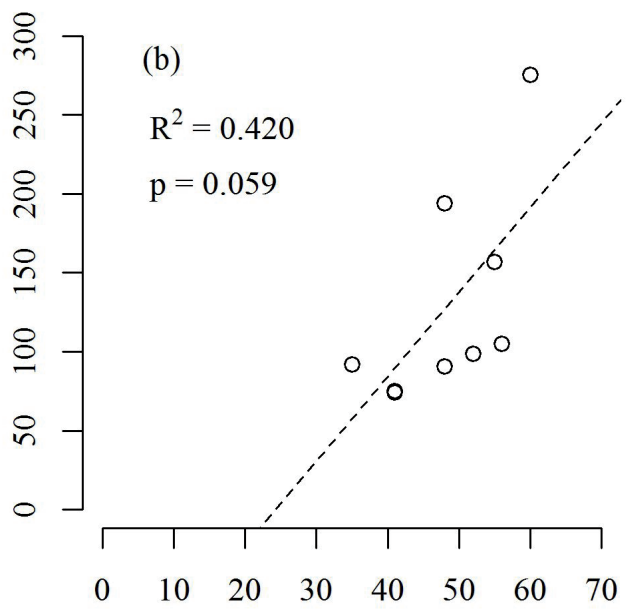

Number of point hits

Figure 1. Relationship between biomass proxy and actual biomass for visual cover estimation (a), and point-intercept sampling (b) based on Dataset 2002. Solid line stands for significant regression $(\mathrm{p}<0.05)$, while dashed line shows marginally significant one $(0.10$ $<\mathrm{p}<0.05)$ 


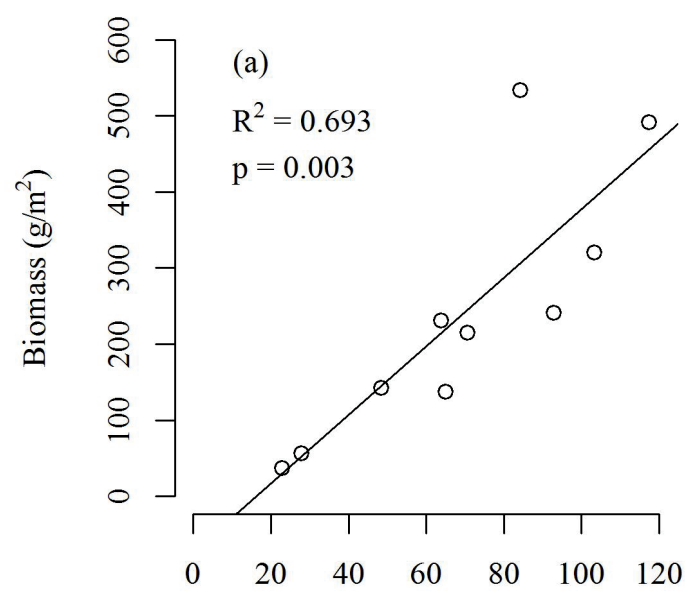

Visually estimated cover (\%)

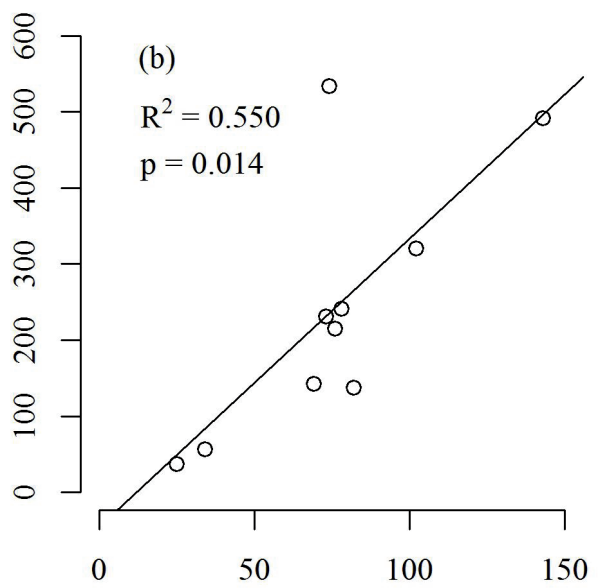

Number of point hits

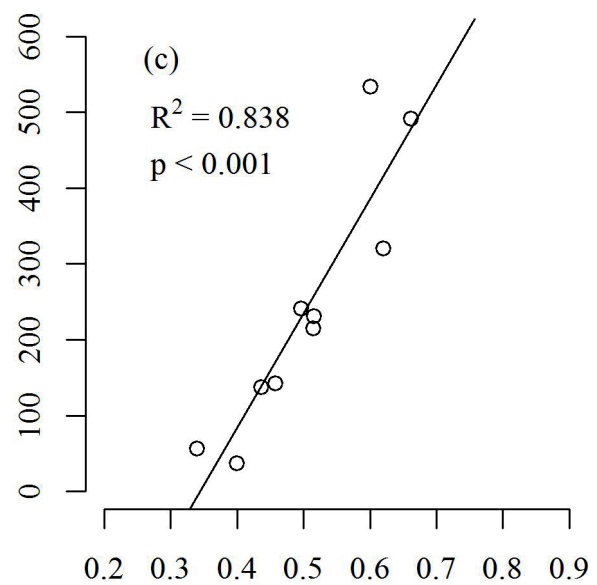

\section{NDVI}

Figure 2. Relationship between biomass proxy and actual biomass for visual cover estimation (a), point intercept method (b), and field spectroscopy (c) based on Dataset 2010. All linear regressions were significant; see the text for details.

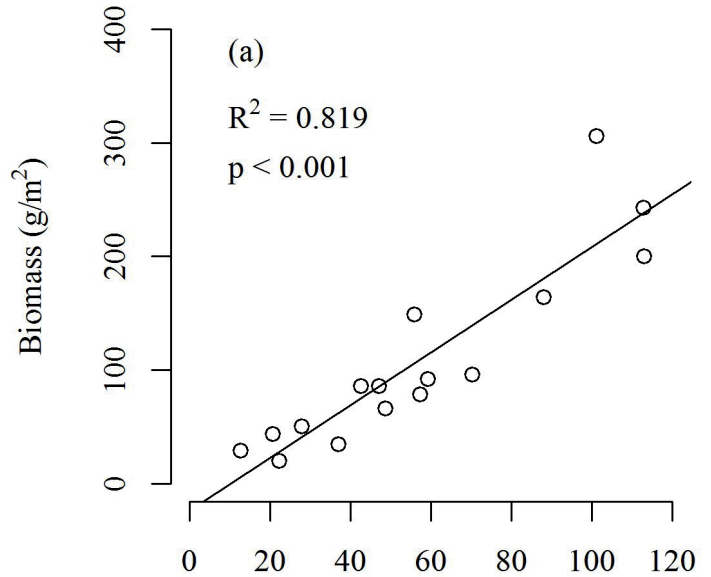

Visually estimated cover (\%)

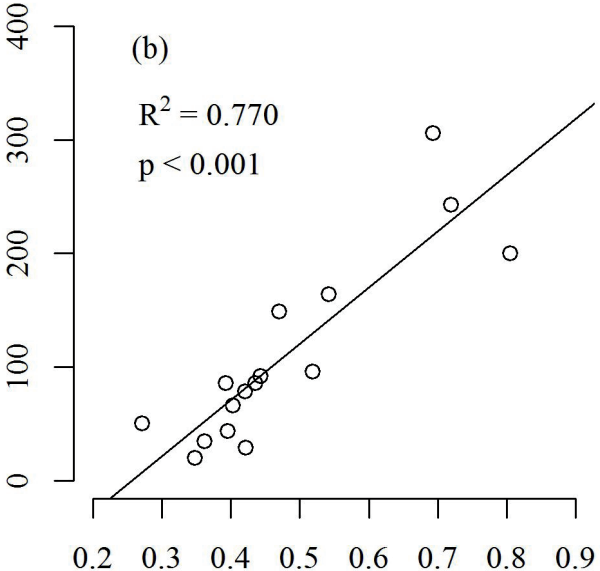

NDVI

Figure 3. Relationship between biomass proxy and actual biomass for visual cover estimation (a) and field spectroscopy (b) based on Dataset 2014. All linear regressions were significant; see the text for details. 
$\mathrm{df}=8, \mathrm{p}=0.003$ ), and point intercept method (Fig. $2 \mathrm{~b}, \mathrm{R}^{2}=$ $0.550, \mathrm{~F}=9.78, \mathrm{df}=8, \mathrm{p}=0.014)$.

For the Dataset 2014, we found high values of the coefficient of determination in both cases; visual cover estimation had higher accuracy (Fig. 3a, $\mathrm{R}^{2}=0.819, \mathrm{~F}=63.49$, df $=14$, $\mathrm{p}<0.001$ ), but regression of biomass with NDVI proved to be also significant (Fig. $3 b, R^{2}=0.770, F=46.75, d f=14, p$ $<0.001)$

\section{Discussion}

Although it is frequently stated in the literature that visual cover estimation is a subjective and less repeatable method (Godínez-Alvarez et al. 2009, Greig-Smith, 1983, Wilson, 2011), we found no evidence that it was less accurate than point intercept method or field spectroscopy in estimating biomass. The accuracy of visual cover estimation was intermediate between that of field spectroscopy and point intercept methods in the Dataset 2010 on which all three methods were studied. For the other two datasets, visual cover estimation proved superior to the other methods studied. Our results are different from those of Godínez-Alvarez et al. (2009), who found visual cover estimation performing poorer than point and line intercept methods for cover estimations. However, they did not compare estimates with harvested biomass, but only looked at coefficient of variation of the estimates. Our results are in agreement with the findings of Döbert et al. (2015), who found that even a semi-quantitative assessment based on Braun-Blanquet scale can provide a reliable proxy for aboveground biomass. Similar to our results, Redjadj et al. (2012) also found that visual cover estimation can be accurate in estimating biomass, although they estimated biomass directly (and not cover), and estimation procedure was preceded by a training series. The relatively weak performance of point intercept method found in our study is in contrast to comparative studies that found good accuracy for this method (Byrne et al. 2011, Godínez-Alvarez et al. 2009). The number of points used to describe the vegetation may affect the reliability of estimation (Bråthen and Hagberg, 2004). However, the numbers of points we used (57 and 60) were above the minimum number recommended for grasslands $\left(40\right.$ per $\mathrm{m}^{2}$; Bråthen and Hagberg, 2004) and were similar to other studies, including methodological comparative studies (Byrne et al. 2011, Godínez-Alvarez et al. 2009, Kongstad et al. 2012). The acceptable accuracy we found for field spectroscopy is in contrast to results of Byrne et al. $(2013,2011)$, who found field spectroscopy less accurate in a three-year field experiment than point intercept method. However, they did not measure incident radiation, which may have decreased the accuracy of the remote sensing method they applied.

In the present study, we evaluated the three methods solely based on their ability to estimate aboveground biomass, but the choice of the method best suited to a particular study may also depend on additional criteria, including add-on values and shortcomings of the different methods. The advantage of visual cover estimation is that it is easily adaptable to different vegetation types and architectures, thus it can be particularly suitable for extensive monitoring studies (Peet et al.
1998). Because of its quickness (Sykes et al. 1983) and low cost (Klimeš, 2003), visual cover estimation is a widely used technique. This method is the most appropriate in studies assessing plant species richness (Godínez-Alvarez et al. 2009), as it includes the search for all species within plots. On the other hand, the observers doing visual cover estimation need to mentally integrate the cover values of a given species in the sampling unit (Godínez-Alvarez et al. 2009), thus training of observers may be crucially important, and reliable visual estimation requires highly experienced field botanist, preferably the same person in a whole field study.

The point intercept method provides information about three dimensional vegetation structure (Godínez-Alvarez et al. 2009, Jonasson, 1988), and repeated point intercept method is also suitable for plant demography studies due to its precise positioning within the sampling unit (Damgaard et al. 2011). However, we found that the method is not superior over other methods in the accuracy of biomass estimation. The results for the Dataset 2010 show the effect of an outlier (Fig 2.), which is caused by the sensitivity of the point intercept method to the highly uneven distribution of the biomass, namely occurrence of poplar shoots in our case. In addition, point intercept method has been found to underestimate species richness (Godínez-Alvarez et al. 2009), most likely because it samples only points, and rare species may be difficult to detect this way. Although this method is considered objective, it is based on many decisions on contact accounts and separation of species and organs, which can be challenging, especially on windy days (Catchpole and Wheeler, 1992). Therefore, between-observer error may cause problems in long-term studies (Filella et al. 2004), similar to visual cover estimation. Vegetation sampling using point intercept method is less time intensive than harvesting biomass (Bråthen and Hagberg, 2004, Byrne et al. 2011, Jonasson, 1988), but it takes more time than field spectroscopy (Byrne et al. 2011). Therefore, point intercept method is recommended only if the additional information it provides is needed.

Field spectroscopy provides the most objective estimate of vegetation abundance, because once the exact location is selected, the measurement does not require decisions from the observer. A major advantage of this method is its quickness (Byrne et al. 2011), but we also found it as accurate in estimating biomass as the more time-demanding visual cover estimation and point intercept methods. It can be a reliable estimator of aboveground live biomass in open communities, where living parts of the plants rarely overlap, and saturation effect (Gu et al. 2013) does not occur. This method requires costly equipment, and favourable weather conditions for the sampling days, as it is constrained by the clearness of the sky and the angle of incident radiation (Roujean and Breon, 1995). As field spectroscopy does not detect vegetation composition (species, life forms) or structure, it can only be appropriate when the focus is on biomass.

The results of the three case studies are in accordance with each other. We conclude that visual cover estimation, which is generally considered subjective, is not less accurate for estimating aboveground biomass than point intercept method and field spectroscopy. Moreover, in the open grass- 
lands, visual cover estimation proved superior to point intercept method. Since all of the studied non-destructive methods estimated the live biomass properly, but they differ in the level of detail they provide about the studied vegetation, the choice amongst the methods should be based on the need for additional data other than biomass and the available time, expertise and equipment.

Acknowledgements. We thank B. Kolonics, Mrs. R. Ribai and Mrs. S. Vadkerti for their help in lab work. We are grateful to the Kiskunság National Park (Hungary) for the support of our field work. This study was funded by the VULCAN project (EU FP5 grant EVK2-CT-2000-00094)), the INCREASE project (EU FP7 grant 227628), the Hungarian Scientific Research Fund (OTKA K112576), the János Bolyai Research Scholarship of the Hungarian Academy of Sciences (Gy. Kröel-Dulay), and the National Research, Development and Innovation Office (GINOP 2.3.3-15-2016-00019).

\section{References}

Asrar, G., Kanemasu, E.T., Miller, G.P. and Weiser, R.L. 1986. Light interception and leaf area estimates from measurements of grass canopy reflectance. IEEE Trans. Geosci. Remote Sens. GE-24: 76-82

Bråthen, K.A. and Hagberg, O. 2004. More efficient estimation of plant biomass. J. Veg. Sci. 15: 653-660.

Braun-Blanquet, J. 1932. Plant Sociology. The Study of Plant Communities. McGraw-Hill, New York.

Byrne, K.M., Lauenroth, W.K. and Adler, P.B. 2013. Contrasting effects of precipitation manipulations on production in two sites within the Central Grassland Region, USA. Ecosystems 16: 1039-1051.

Byrne, K.M., Lauenroth, W.K., Adler, P.B. and Byrne, C.M., 2011. Estimating aboveground net primary production in grasslands: A comparison of nondestructive methods. Rangel. Ecol. Manag. 64: 498-505

Canfield, R.H. 1941. Application of the line interception method in sampling range vegetation. J. For. 39: 388-394.

Catchpole, W.R. and Wheeler, C.J. 1992. Estimating plant biomass: A review of techniques. Aust. J. Ecol. 17: 121-131.

Damgaard, C., Merlin, A., Mesléard, F. and Bonis, A. 2011. The demography of space occupancy: measuring plant colonization and survival probabilities using repeated pin-point measurements. Methods Ecol. Evol. 2: 110-115.

Döbert, T.F., Webber, B.L., Sugau, J.B., Dickinson, K.J.M. and Didham, R.K. 2015. Can leaf area index and biomass be estimated from Braun-Blanquet cover scores in tropical forests? $J$. Veg. Sci. 26: 1043-1053

Faraway, J.J. 2005. Linear Models with R. CRC Press, Boca Raton.

Fay, P.A., Blair, J.M., Smith, M.D., Nippert, J.B., Carlisle, J.D. and Knapp, A.K. 2011. Relative effects of precipitation variability and warming on tallgrass prairie ecosystem function. Biogeosciences 8: 3053-3068.

Filella, I., Peñuelas, J., Llorens, L. and Estiarte, M. 2004. Reflectance assessment of seasonal and annual changes in biomass and $\mathrm{CO}_{2}$ uptake of a Mediterranean shrubland submitted to experimental warming and drought. Remote Sens. Environ. 90: 308-318.
Frank, D.A. and McNaughton, S.J. 1990. Aboveground biomass estimation with the canopy intercept method: A plant growth form caveat. Oikos 57: 57-60.

Gamon, J.A., Field, C.B., Goulden, M.L., Griffin, K.L., Hartley, A.E., Joel, G., Peñuelas, J. and Valentini, R. 1995. Relationships between NDVI, canopy structure, and photosynthesis in three Californian vegetation types. Ecol. Appl. 5: 28-41.

Gilgen, A.K. and Buchmann, N. 2009. Response of temperate grasslands at different altitudes to simulated summer drought differed but scaled with annual precipitation. Biogeosciences 6: 25252539.

Godínez-Alvarez, H., Herrick, J.E., Mattocks, M., Toledo, D. and Van Zee, J. 2009. Comparison of three vegetation monitoring methods: Their relative utility for ecological assessment and monitoring. Ecol. Indic. 9: 1001-1008.

Goodall, D. 1952. Some considerations in the use of point quadrats for the analysis of vegetation. Aust. J. Biol. Sci. 5: 1-41.

Greig-Smith, P. 1983. Quantitative Plant Ecology. University of California Press, Berkeley.

Grime, J.P., Fridley, J.D., Askew, A.P., Thompson, K., Hodgson, J.G. and Bennett, C.R. 2008. Long-term resistance to simulated climate change in an infertile grassland. Proc. Natl. Acad. Sci. 105: 10028-10032.

Gu, Y., Wylie, B.K., Howard, D.M., Phuyal, K.P. and Ji, L. 2013. NDVI saturation adjustment: A new approach for improving cropland performance estimates in the Greater Platte River Basin, USA. Ecol. Indic. 30: 1-6.

Hahn, I. and Scheuring, I. 2003. The effect of measurement scales on estimating vegetation cover: a computer-assisted experiment. Community Ecol. 4: 29-33.

Jobbágy, E.G., Sala, O.E. and Paruelo, J.M. 2002. Patterns and controls of primary production in the Patagonian steppe: a remote sensing approach. Ecology 83: 307-319.

Jonasson, S. 1988. Evaluation of the point intercept method for the estimation of plant biomass. Oikos 52: 101-106.

Klimeš, L. 2003. Scale-dependent variation in visual estimates of grassland plant cover. J. Veg. Sci. 14: 815-821.

Knapp, A., Carroll, C.W., Denton, E., La Pierre, K., Collins, S. and Smith, M. 2015. Differential sensitivity to regional-scale drought in six central US grasslands. Oecologia 177: 949-957.

Kongstad, J., Schmidt, I.K., Riis-Nielsen, T., Arndal, M.F. Mikkelsen, T.N. and Beier, C. 2012. High resilience in heathland plants to changes in temperature, drought, and $\mathrm{CO}_{2}$ in combination: Results from the CLIMAITE experiment. Ecosystems 15: 269-283

Kovács-Láng, E., Kröel-Dulay, G., Kertész, M., Fekete, G., Mika, J., Dobi-Wantuch, I., Rédei, T., Rajkai, K., Hahn, I. and Bartha, S. 2000. Changes in the composition of sand grasslands along a climatic gradient in Hungary and implications for climate change. Phytocoenologia 30: 385-408.

Kovács-Láng, E., Molnár, E., Kröel-Dulay, G. and Barabás, S. 2008. The KISKUN LTER: Long-term ecological research in the Kiskunság, Hungary. Institute of Ecology and Botany, Hungarian Academy of Sciences, Vácrátót.

Kröel-Dulay, G., Ransijn, J., Schmidt, I.K., Beier, C., De Angelis, P., de Dato, G., Dukes, J.S., Emmett, B., Estiarte, M., Garadnai, J., Kongstad, J., Kovács-Láng, E., Larsen, K.S., Liberati, D., Ogaya, R., Riis-Nielsen, T., Smith, A.R., Sowerby, A., Tietema, A. and Penuelas, J. 2015. Increased sensitivity to climate change in disturbed ecosystems. Nat. Commun. 6: 6682 doi:10.1038/ ncomms 7682 . 
Milton, E.J., Schaepman, M.E., Anderson, K., Kneubühler, M. and Fox, N. 2009. Progress in field spectroscopy. Remote Sens. Environ., Imaging Spectroscopy Special Issue 113, Supplement 1: S92-S109.

Molnár, Z. 2003. Sanddunes in Hungary (Kiskunság). TermészetBÚVÁR Alapítvány Kiadó, Budapest.

Nemani, R.R., Keeling, C.D., Hashimoto, H., Jolly, W.M., Piper, S.C., Tucker, C.J., Myneni, R.B. and Running, S.W. 2003. Climate-driven increases in global terrestrial net primary production from 1982 to 1999. Science 300: 1560-1563.

Paruelo, J.M., Epstein, H.E., Lauenroth, W.K. and Burke, I.C. 1997. ANPP estimates from NDVI for the Central Grassland Region of the United States. Ecology 78: 953-958.

Pearson, R.L., Miller, L.D. and Tucker, C.J. 1976. Hand-held spectral radiometer to estimate gramineous biomass. Appl. Opt. 15: 416-418.

Peet, R.K., Wentworth, T.R. and White, P.S. 1998. A flexible, multipurpose method for recording vegetation composition and structure. Castanea 63: 262-274.

Peñuelas, J., Prieto, P., Beier, C., Cesaraccio, C., De ANGELIS, P., De DATO, G., Emmett, B.A., Estiarte, M., Garadnai, J., Gorissen, A., Láng, E.K., Kröel-Dulay, G., Llorens, L., Pellizzaro, G., Riis-Nielsen, T., Schmidt, I.K., Sirca, C., Sowerby, A., Spano, D. and Tietema, A. 2007. Response of plant species richness and primary productivity in shrublands along a north-south gradient in Europe to seven years of experimental warming and drought: reductions in primary productivity in the heat and drought year of 2003. Glob. Change Biol. 13: 2563-2581.

R Core Team, 2013. R: A language and environment for statistical computing. R Foundation for Statistical Computing, Vienna, Austria. URL http://www.R-project.org/.

Redjadj, C., Duparc, A., Lavorel, S., Grigulis, K., Bonenfant, C., Maillard, D., Saïd, S. and Loison, A. 2012. Estimating herbaceous plant biomass in mountain grasslands: a comparative study using three different methods. Alp. Bot. 122: 57-63.

Röttgermann, M., Steinlein, T., Beyschlag, W. and Dietz, H. 2000. Linear relationships between aboveground biomass and plant cover in low open herbaceous vegetation. J. Veg. Sci. 11: 145148.

Roujean, J.-L. and Breon, F.-M. 1995. Estimating PAR absorbed by vegetation from bidirectional reflectance measurements. Remote Sens. Environ. 51: 375-384.

Rouse, J.W., Haas, R.H., Deering, D.W., Schell, J.A. and Harlan, J.C. 1974. Monitoring the vernal advancement and retrogradation (green wave effect) of natural vegetation. NASA/GSFCT Type III Final Report, Greenbelt, MD, USA.

Sala, O.E. and Austin, A.T. 2000. Methods of estimating aboveground net primary productivity. In: Sala, O.E., Jackson, R.B., Mooney, H.A. and Howarth, R.W. (eds.), Methods in Ecosystem Science. Springer New York, pp. 31-43.

Sala, O.E., Parton, W.J., Joyce, L.A. and Lauenroth, W.K. 1988. Primary production of the Central Grassland Region of the United States. Ecology 69: 40-45.

Scurlock, J.M.O., Johnson, K. and Olson, R.J. 2002. Estimating net primary productivity from grassland biomass dynamics measurements. Glob. Change Biol. 8: 736-753.

Sykes, J.M., Horrill, A.D. and Mountford, M.D. 1983. Use of visual cover assessments as quantitative estimators of some British woodland taxa. J. Ecol. 71: 437-450.

The Plant List, 2010. Version 1. Published on the Internet; http:// www.theplantlist.org/ (accessed 1st January).

Tucker, C.J. and Sellers, P.J. 1986. Satellite remote sensing of primary production. Int. J. Remote Sens. 7: 1395-1416.

Whitbeck, M. and Grace, J.B. 2006. Evaluation of non-destructive methods for estimating biomass in marshes of the upper Texas, USA coast. Wetlands 26: 278-282.

Wilson, J.B. 2011. Cover plus: ways of measuring plant canopies and the terms used for them. J. Veg. Sci. 22: 197-206.

Wintle, B.C., Fidler, F., Vesk, P.A., L. Moore, J. 2013. Improving visual estimation through active feedback. Methods Ecol. Evol. 4: 53-62.

Received December 6, 2016

Revised April 3, 2017

Accepted May 2, 2017 